International Journal of Anesthesiology \& Research (IJAR)

ISSN 2332-2780

\title{
Does Endotracheal Tube Design Affect Cuff Seal, Safety and Subglottic Suction Performance: An in-vitro study?
}

Lichtenthal $\mathrm{P}^{1^{*}}$, Borg $\mathrm{U}^{2}$, Lockett $\mathrm{W}^{3}$

${ }^{1}$ Professor, Department of Anesthesiology, University of Arizona, Health Science Center-College of Medicine, Tucson, AZ, USA.

${ }^{2}$ Director Clinical Science, Medtronic Corporation, Covidien Division, Boulder, CO, USA.

${ }^{3}$ Senior Scientific Manager and Chief Scientist, Avivid Technologies Group, Longmont, CO, USA.

\section{Abstract}

Introduction: Ideally endotracheal tubes (ETT) should protect the airways without causing pressure induced tissue damage. Traditionally, the addition of a tracheal cuff was heralded as seal against aspiration. This type of ETT utilized a low volume high pressure cuff which caused tracheal damage such as stenosis and malacia. The next development in ETT design was the high volume low pressure cuffs intended to protect the airways while reducing tissue damage. Although reducing damage, the new cuff did not reliably protect the airways. Microaspiration still remains a serious complication of intubation. A taper shaped cuff design was recently introduced to prevent microaspiration without causing tracheal damage. Concerns were raised regarding the contact area and the resultant pressure against the tracheal wall of the taper shaped cuff. Another innovation introduced to prevent microaspiration is subglottic suction present in the tube design. Therefore, the aim of this paper is to evaluate cuff seal performance, cuff safety and intrinsic suction efficiency of current commercially available ETT.

Methods: Three separate studies evaluated these areas of interest. Cuff seal performance was evaluated using an approved in vitro test fixture mimicking the human trachea. We investigated the cuff seal performance of 7 endotracheal tubes with different cuff designs and identical tracheal tube size using water as the medium. Three different size tubes from 3 different manufacturers were tested to determine subglottic suction efficiency and cuff sealing performance using the same in vitro test fixture. In a similar fixture a pressure sensitive array was mounted to compare the surface pressure of a standard barrel shaped cuff to the taper shaped cuff. The array design allowed for the pressure profile of the cuff to be mapped where it contacted the cylinder wall. In all tests the cuff pressures were maintained at $25 \mathrm{~cm} \mathrm{H}_{2} \mathrm{O}$ according to manufacturer's recommendations.

Results: The sealing performance varied between the tube manufacturers with TaperGuard (TG) showing the lowest leak at $.6 \mathrm{~g} / 5$ minutes and Kimberly Clark Micro cuff ( $\mathrm{KCmc}$ ) with the highest $59.2 \mathrm{~g} / 5$ minutes. In terms of suction efficiency Teleflex ISIS (ISIS) had the best suction performance $(.2-5.3 \mathrm{ml} / \mathrm{sec})$ at all viscosities and Portex (SACETT) $(.3-2.9 \mathrm{ml} / \mathrm{min})$ was the lowest. When comparing surface force the taper shaped cuff was less compared to the barrel shaped cuff.

Conclusions: Performance in all areas tested ETTs varied considerably in terms of sealing and suction efficiency. However, the taper shaped cuff demonstrated the least surface pressure and best sealing.

\section{*Corresponding Author:}

\section{Peter Lichtenthal MD,}

The University of Arizona Health Science Center-College of Medicine, 1501 North Campbell Avenue, Tucson, AZ 85724, USA.

Tel: 520-626-7636

Fax: 520-626-6943

E-mail: plich@email.arizona.edu

Received: October 17, 2015

Accepted: November 17, 2015

Published: November 19, 2015

Citation: Lichtenthal P, Borg U, Lockett W (2015) Does Endotracheal Tube Design Affect Cuff Seal, Safety and Subglottic Suction Performance: An in-vitro study?. Int J Anesth Res. 3(10), 166-171. doi: http:// dx.doi.org/10.19070/2332-2780-1500041

Copyright: Lichtenthal $\mathbf{P}^{\circ}$ 2015. This is an open-access article distributed under the terms of the Creative Commons Attribution License, which permits unrestricted use, distribution and reproduction in any medium, provided the original author and source are credited.

\section{Introduction}

The ideal endotracheal tube should protect the airways while not causing pressure induced tissue damage in the trachea. Traditionally, the addition of a tracheal balloon cuff was heralded as a seal against aspiration. However, this type cuff utilized low volume high pressure cuff design which was proven to cause tracheal damage such as tracheal stenosis and tracheal malacia [1]. The next development in endotracheal tube design was the introduction of high volume low pressure cuffs intended to protect the airways while reducing tissue damage [2]. The low pressure high volume cuff was designed with a resting diameter greater than the diameter of the trachea. Although reducing tissue damage, the new cuff design did not reliably protect the airways since leaks occurred around the cuff $[3,4]$. Pulmonary microaspiration still remains a serious complication of tracheal intubation resulting in post-intubation pulmonary complications [5]. A new taper shaped cuff design was recently introduced whose aim is to prevent microaspiration without causing tissue damage in the trachea. The taper shaped cuff design is thought to allow the cuff diameter to 
match the tracheal diameter at some point of the length of the cuff. However, concerns have been raised regarding the contact area of this smaller cuff and the resultant pressure against the tracheal wall.

Another innovation introduced to reduce the risk of microaspiration is the ability to evacuate secretions collecting on top of the cuff by incorporating subglottic suction as part of the tube design. This hopefully will reduce the risk of microaspiration and decrease the incidence of post-intubation pulmonary complications. Any change to the design of an endotracheal tube results in a cost increase. Therefore, the aim of the studies in this paper is to evaluate cuff seal performance, cuff safety and intrinsic suction efficiency of current commercially available ETT.

\section{Methods}

Three separate but linked studies were initiated to evaluate the areas of interest. In the first part of our study cuff seal performance was evaluated using an approved in vitro test fixture, without suction collection setup, (Figure 1) mimicking the human trachea (ISO 5361Annex B) [6]. We investigated the cuff seal performance of 7 endotracheal tubes with different cuff designs and identical tracheal tube size (I.D. $7.5 \mathrm{~mm}$ ) using water as the medium (Hi-Lo and TaperGuard, Covidien, Bolder CO, Micro Cuff, Kimberly Clark, Roswell, GA, BARD Agento, BARD, Murray Hill, NJ, Portex and BlueLine, Smith-Medical, Dublin, $\mathrm{OH}$, Sheridan HVT, Hudson RCI, Duram, NC). Ten milliliter of water was placed on top of the inflated cuff and the total volume of fluid leaked in 5 minutes was recorded. A total of 50 observations were performed for each tube type.

In the second part of the study, three different size tubes (I.D. $=6 \mathrm{~mm}, 7.5 \mathrm{~mm}$ and $9 \mathrm{~mm}$ ) from 3 different manufacturers (TaperGuard EVAC, Covidien, Boulder, CO, Teleflex ISIS, Teleflex, Duram, NC, PortexBlue-line Saccet, Smith-Medical, Dublin, $\mathrm{OH}$ ) were tested to determine subglottic suction efficiency and cuff sealing performance using the same in vitro test fixture (Figure 1). The suctioning performance at intermittent (15 seconds on and 8 seconds off) suction of $150 \mathrm{mmHg}$ (OHIO suction regulator, OHIO Medical Corporation, Gurnee, IL) and leakage rate was measured using silicon based liquids (Brookfield Engineering, Middleboro, MA) of 3 viscosities (0.5Pa.s, 5.0Pa.s, 12.5Pa.s) representing normal saliva [7], sinus drainage [8] and gastric mucus [9]. The liquids were placed on top of the endotracheal tube cuff (Table 1). The suction test was repeated 20 times for each size and manufacturer for a total of 180 tubes. During each test in the in vitro test fixture a weigh boat under the inflated cuff was used to collect any drips that leaked past the cuff. A reservoir connected to suction was used to collect liquid from the EVAC lumen of the endotracheal tube. Pre and post test weights were recorded for the weigh boat and reservoir as was time elapsed to calculate suction and leak rates.

In the final part of the study, a similar in vitro test fixture (Figure 2) utilized a pressure sensitive array (Pressure Profile Systems, Inc., Los Angeles, CA) which was mounted to compare the surface pressure of a standard barrel shaped cuff to the taper shaped cuff. The inside diameter of this fixture is $20.0 \mathrm{~mm}$, the standard diameter for testing $7.5 \mathrm{~mm}$ endotracheal tubes. The pressure array is made up of $32 \times 25$ capacitative sensor elements, with each element measuring $2.0 \mathrm{~mm} \times 2.0 \mathrm{~mm}$. The design of this array allows for the pressure profile of the cuff to be mapped along its entire circumference where it contacts the cylinder wall (artificial trachea). The average and maximum pressures along with the contact area were measured for each tube tested. The overall average of each of these parameters was then calculated for the barrel shaped cuffs and the taper shaped cuffs. The pressure array fixture is not able to measure force directly, so the force exerted by the cuff on the cylinder wall was calculated from the pressure and contact area measurements according to the formula; Pressure $=$ Force $/$ Area. The force is thus calculated as the sum of the pressure at each element times the surface area of each element. In all tests the cuff pressures were maintained at $25 \mathrm{~cm} \mathrm{H}_{2} \mathrm{O}$ according to manufacturer's recommendations.

Statistical analysis was performed on all tests using analysis of variance, F-test and t-test, where appropriate. A $\mathrm{p}$ value of less than 0.05 was considered statistically significant.

\section{Results}

The results for cuff sealing performance are listed in Table 2 and all results are presented as mean and standard deviation. As can be seen in the table the TaperGuard endotracheal tube had the smallest leak at $0.59 \pm 0.99 \mathrm{~g} \mathrm{H}_{2} \mathrm{O} / 5 \mathrm{~min}$ and in this test, the KimberlyClark Micro cuff had the greatest leak at $59.18 \pm 83.96 \mathrm{~g} \mathrm{H}_{2} \mathrm{O} / 5$ min. The results from the second part of the study demonstrates that Teleflex ISIS although not reaching statistical significance in all categories, had the best suction performance compared to $\mathrm{Ta}$ perGuard and SACETT at all viscosities (Figure 3). TaperGuard and SACETT demonstrated similar suction efficiency with better performance from the TaperGuard at higher mucous viscosities (Figure 3). The biggest differences in suction efficiency was found in the $7.5 \mathrm{~mm}$ and $9.0 \mathrm{~mm}$ endotracheal tubes where Teleflex ISIS demonstrated suction rates of 0.35 to $5.33 \mathrm{ml} / \mathrm{min}$ for the most to the least viscous mucous compared to TaperGuard 0.21 to 2.52 $\mathrm{ml} / \mathrm{min}$ and SACETT 0.18 to $2.02 \mathrm{ml} / \mathrm{min}$.

Figure 1. Test setup for both cuff sealing performance and subglottic suction efficiency.

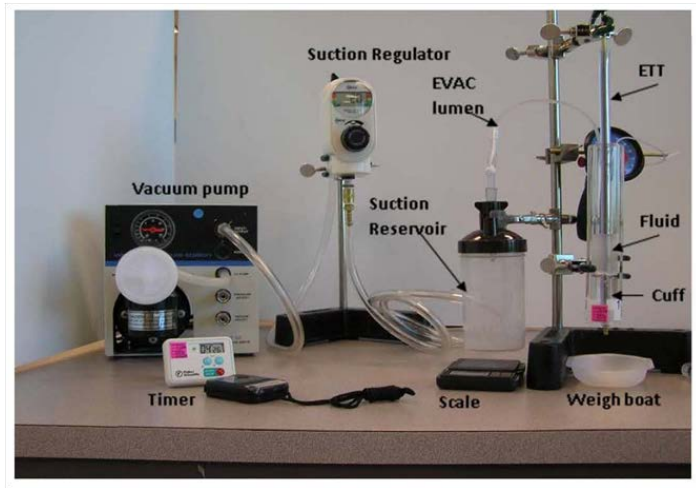


Table 1. Suction times and volumes installed for the subglottic suction efficiency evaluation.

\begin{tabular}{|c|c|c|c|c|c|}
\hline $\begin{array}{c}\text { Tube Size } \\
\text { (I.D.) }\end{array}$ & $\begin{array}{c}\text { Suction } \\
\text { Mode }\end{array}$ & $\begin{array}{c}\text { Suction } \\
\text { Pressure }\end{array}$ & Test Solution & $\begin{array}{c}\text { Suction } \\
\text { Time }\end{array}$ & $\begin{array}{c}\text { Required } \\
\text { Volume }\end{array}$ \\
\hline $6.0 \mathrm{~mm}$ & Intermittent & \multirow{2}{*}{$150 \mathrm{mmHg}$} & Low Viscosity Simulant & $45 \mathrm{sec}$ & $23 \mathrm{~mL}$ \\
\cline { 4 - 6 } & & & Medium Viscosity Simulant & $30 \mathrm{~min}$ & $10 \mathrm{~mL}$ \\
\cline { 4 - 6 } & & & High Viscosity Simulant & $45 \mathrm{~min}$ & $10 \mathrm{~mL}$ \\
\hline $7.5 \mathrm{~mm}$ & Intermittent & \multirow{2}{*}{$150 \mathrm{mmHg}$} & Low Viscosity Simulant & $1 \mathrm{~min}$ & $35 \mathrm{~mL}$ \\
\cline { 4 - 6 } & & & Medium Viscosity Simulant & $20 \mathrm{~min}$ & $15 \mathrm{~mL}$ \\
\cline { 4 - 6 } & & & High Viscosity Simulant & $45 \mathrm{~min}$ & $10 \mathrm{~mL}$ \\
\hline \multirow{2}{*}{$9.0 \mathrm{~mm}$} & Intermittent & \multirow{2}{*}{$150 \mathrm{mmHg}$} & Low Viscosity Simulant & $45 \mathrm{sec}$ & $40 \mathrm{~mL}$ \\
\cline { 4 - 6 } & & & Medium Viscosity Simulant & $20 \mathrm{~min}$ & $15 \mathrm{~mL}$ \\
\cline { 4 - 6 } & & & High Viscosity Simulant & $30 \mathrm{~min}$ & $10 \mathrm{~mL}$ \\
\hline
\end{tabular}

Figure 2. Pressure sensitive grid for surface force testing.

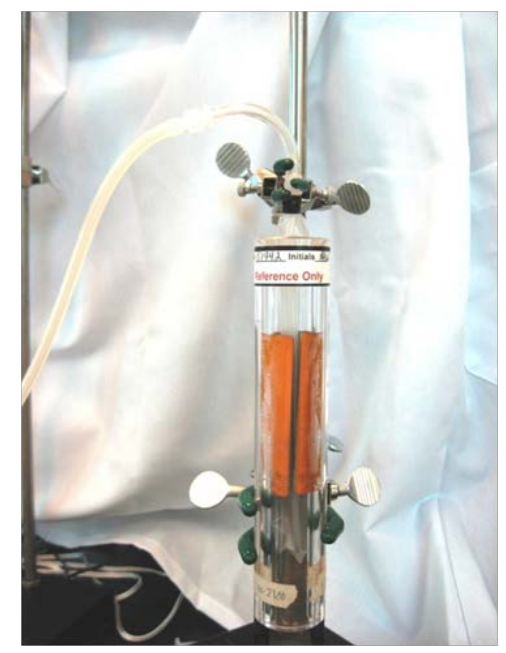

Table 2. Result of cuff sealing performance testing. Values are presented as mean and \pm SD. $P$ values represent comparison to Covidien TaperGuard.

\begin{tabular}{|c|c|c|c|}
\hline Tracheal Tube & Leak Rate(mean) & Leak Rate $\mathbf{\pm S D}$ & p value \\
\hline Covidien TaperGuard & 0.59 & 0.99 & \\
\hline Covidien Hi-Lo & 11.19 & 4.73 & $<0.001$ \\
\hline Hudson BCI Sheridan HVT & 31.31 & 18.88 & $<0.001$ \\
\hline SmithsPortex Soft-Seal & 38.17 & 19.29 & $<0.001$ \\
\hline Bard Agento & 38.18 & 13.68 & $<0.001$ \\
\hline SmithsPortex Soft-Seal SACETT & 42.21 & 21.61 & $<0.001$ \\
\hline Kimberly Clarke MicroCuff & 59.18 & 83.96 & $<0.001$ \\
\hline
\end{tabular}

The TaperGuard demonstrated the best cuff sealing performance (Figure 4) and had the lowest leak rate compared to SACETT and Teleflex ISIS in all tube sizes and mucous viscosities (Figure 4 and Table 3).

In the third part of the study, representative pressure profiles of a barrel shaped and a taper shaped cuff were determined (Figure 5). As can be expected, the barrel shaped cuffs consistently showed a larger contact area with the wall compared to the taper shaped cuffs. However, the barrel shaped cuffs showed a wider extreme of pressures, with more hot spots (areas of high pressure) compared to the taper shaped cuffs. It should be noted that the hot spots represented pressures higher than the cuff inflation pressure. The average force exerted on the cylinder wall by the barrel shape cuffs was $527 \pm 34 \mathrm{gf}$ (gram-force) and the average force exerted on the cylinder wall by the taper shape cuffs was $373 \pm$ $32 \mathrm{gf}$ which is significantly different $(\mathrm{p}<0.001)$.

\section{Discussion}

We performed a three part study to characterize the influence of design on performance of ET'Ts in terms of cuff sealing, subglottic suction efficiency and cuff surface pressure utilizing an internationally accepted in vitro model. This was done because of the difficulty, risk and invasiveness of evaluating these parameters in vivo. In the first part of the study we utilized commercially available ETTs used in clinical practice to evaluate cuff sealing performance. In the second part we utilized all commercially 
Figure 3. Suction rates for all endotracheal tubes with varying mucous viscosity.
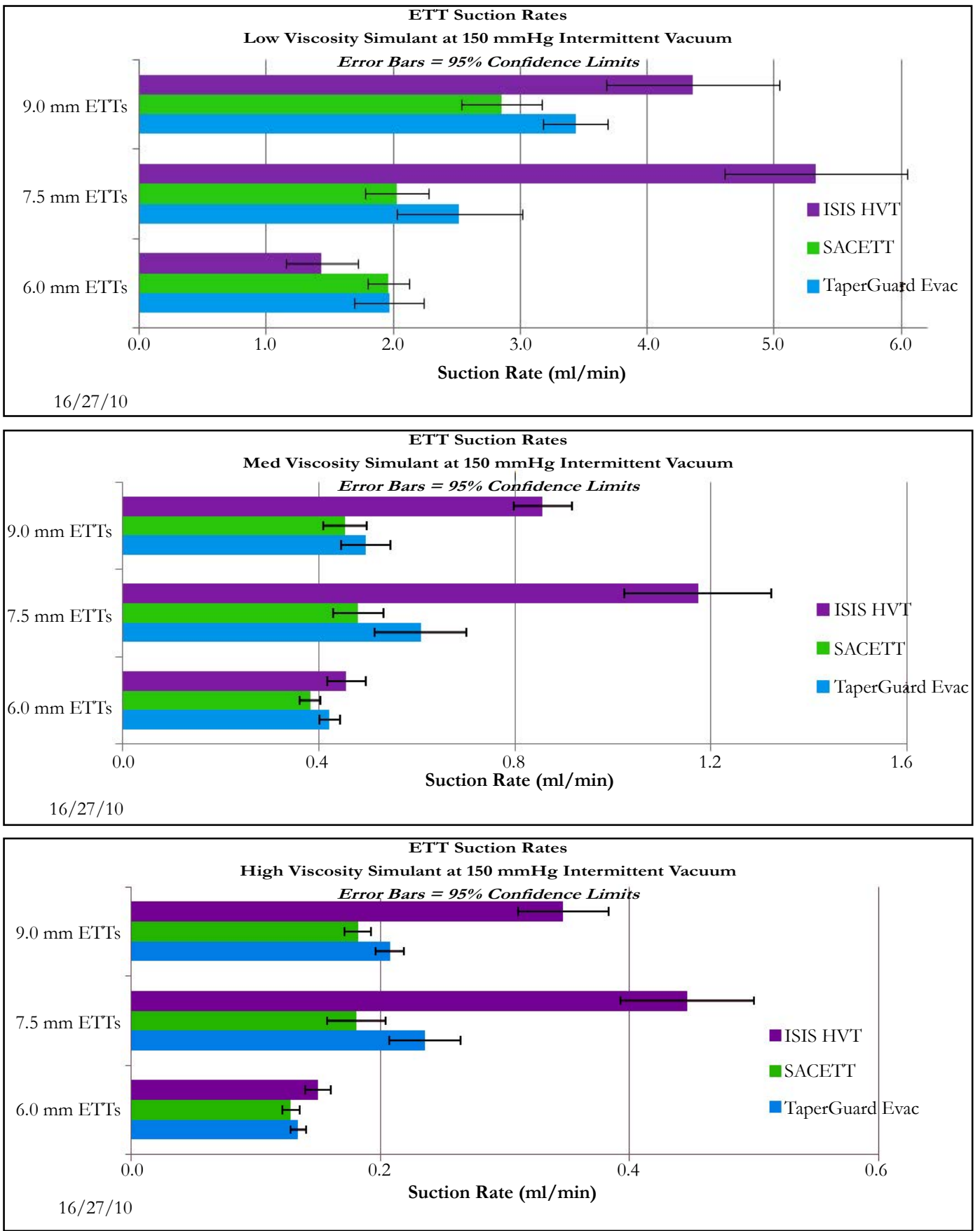

Figure 4. Leak rates for all endotracheal tubes at varying mucous viscosity.

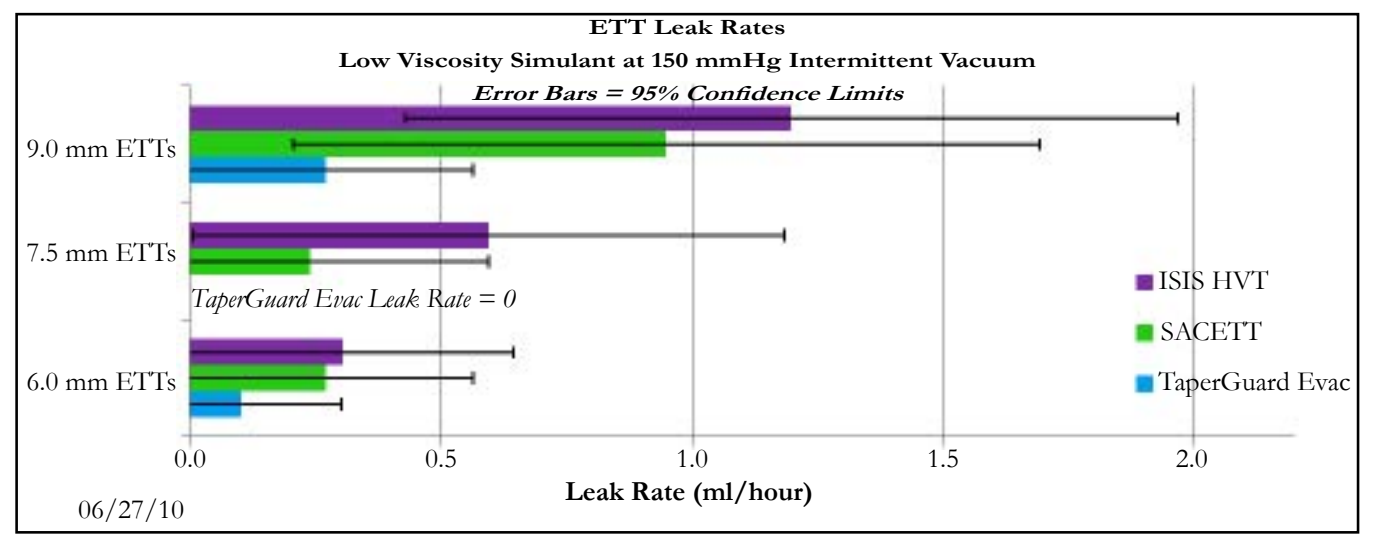



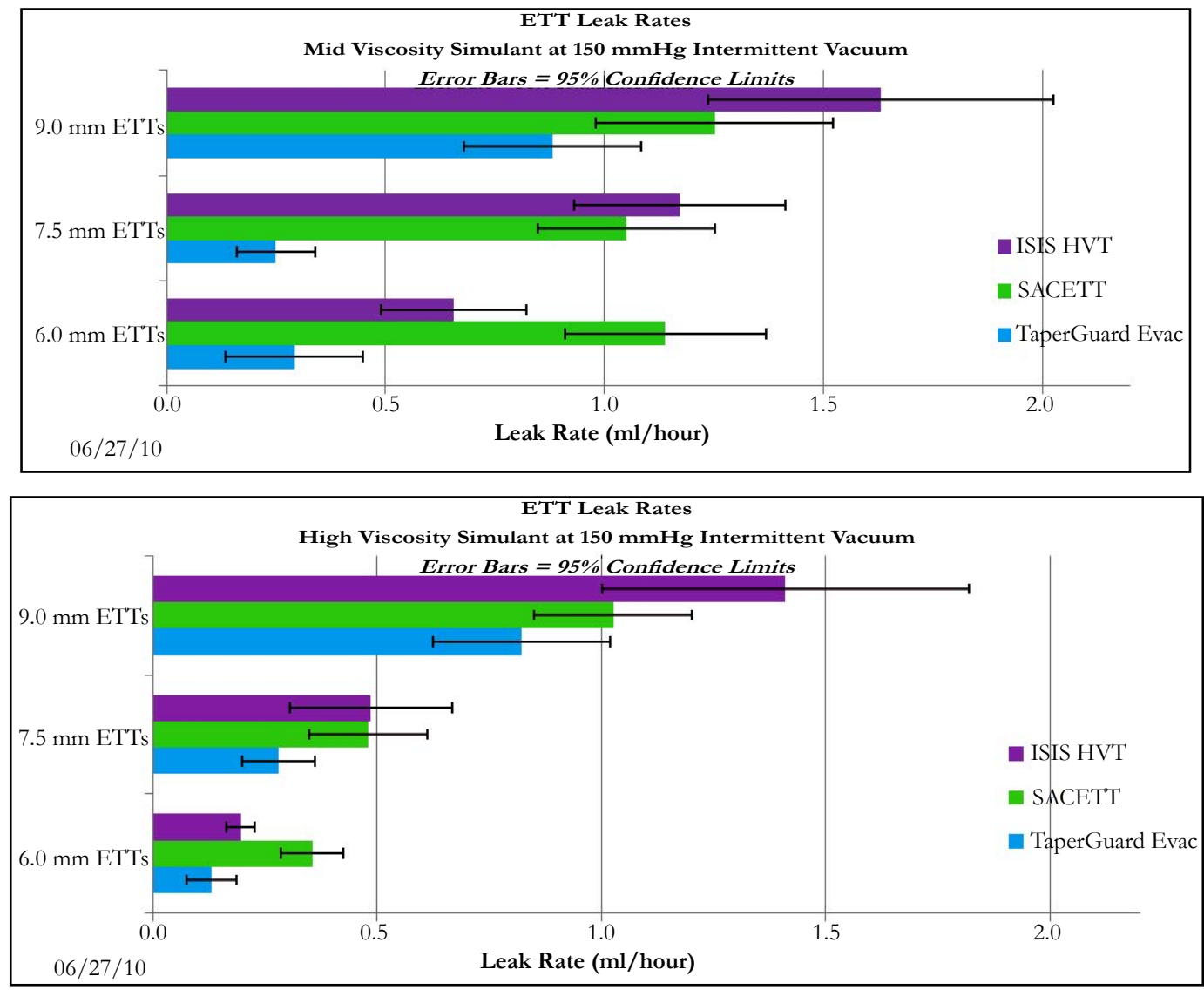

Table 3. Comparisons of leak rates (see also Figure 4 for graphical presentation) for all endotracheal tubes with subglottic suction feature.

\begin{tabular}{|c|c|c|c|c|c|c|c|c|c|c|c|}
\hline $\begin{array}{c}6.0 \mathrm{~mm} \\
\text { ETT Low } \\
\text { viscosity }\end{array}$ & $\begin{array}{c}\text { TaperGuard } \\
\text { EVAC }\end{array}$ & $\begin{array}{c}\text { Portex } \\
\text { SACETT }\end{array}$ & $\begin{array}{l}\text { Teleflex } \\
\text { ISIS }\end{array}$ & $\begin{array}{l}\text { 6.0mm ETT Me- } \\
\text { dium viscosity }\end{array}$ & $\begin{array}{c}\text { TaperGuard } \\
\text { EVAC }\end{array}$ & $\begin{array}{c}\text { Portex } \\
\text { SACETT }\end{array}$ & $\begin{array}{l}\text { Teleflex } \\
\text { ISIS }\end{array}$ & $\begin{array}{l}\text { 6.0mm ETT High } \\
\text { viscosity }\end{array}$ & $\begin{array}{l}\text { Taper- } \\
\text { Guard } \\
\text { EVAC }\end{array}$ & $\begin{array}{c}\text { Portex } \\
\text { SACETT }\end{array}$ & $\begin{array}{l}\text { Teleflex } \\
\text { ISIS }\end{array}$ \\
\hline $\begin{array}{c}\text { Mean } \pm \text { SD } \\
(\mathrm{ml} / \mathrm{hr})\end{array}$ & $0.10 \pm .43$ & $0.27 \pm .64$ & $\begin{array}{r}0.30 \\
\pm .73 \\
\end{array}$ & $\begin{array}{c}\text { Mean } \pm \text { SD (ml/ } \\
\mathrm{hr})\end{array}$ & $0.29 \pm .34$ & $1.14 \pm .50$ & $0.65 \pm .36$ & Mean \pm SD $(\mathrm{ml} / \mathrm{hr})$ & $0.13 \pm .12$ & $0.36 \pm .15$ & $\begin{array}{l}0.20 \\
\pm .07 \\
\end{array}$ \\
\hline $\begin{array}{c}\text { TaperGuard } \\
\text { EVAC }\end{array}$ & & $\mathrm{P}<.32$ & $\mathrm{P}<.31$ & $\begin{array}{c}\text { TaperGuard } \\
\text { EVAC }\end{array}$ & & $\mathrm{P}<.00002$ & $\mathrm{P}<.02$ & TaperGuard EVAC & & $\mathrm{P}<.0007$ & $\mathrm{P}<.28$ \\
\hline $\begin{array}{c}\text { Portex } \\
\text { SACETT } \\
\end{array}$ & $\mathrm{P}<.32$ & & $\mathrm{P}<.79$ & Portex SACETT & $\mathrm{P}<.00002$ & & $\mathrm{P}<.004$ & Portex SACETT & $\mathrm{P}<.0007$ & & $\mathrm{P}<.002$ \\
\hline $\begin{array}{l}\text { Teleflex } \\
\text { ISIS }\end{array}$ & $\mathrm{P}<.31$ & $\mathrm{P}<.79$ & & Teleflex ISIS & $\mathrm{P}<.02$ & $\mathrm{P}<.004$ & & Teleflex ISIS & $\mathrm{P}<.28$ & $\mathrm{P}<.002$ & \\
\hline
\end{tabular}

\begin{tabular}{|c|c|c|c|c|c|c|c|c|c|c|c|}
\hline $\begin{array}{l}7.5 \mathrm{~mm} \\
\text { ETT Low } \\
\text { viscosity }\end{array}$ & $\begin{array}{l}\text { Taper- } \\
\text { Guard } \\
\text { EVAC }\end{array}$ & $\begin{array}{c}\text { Portex } \\
\text { SAC- } \\
\text { ETT }\end{array}$ & $\begin{array}{l}\text { Tel- } \\
\text { eflex } \\
\text { ISIS }\end{array}$ & $\begin{array}{l}\text { 7.5mm ETT Me- } \\
\text { dium viscosity }\end{array}$ & $\begin{array}{l}\text { Taper- } \\
\text { Guard } \\
\text { EVAC }\end{array}$ & $\begin{array}{l}\text { Portex } \\
\text { SACETT }\end{array}$ & $\begin{array}{l}\text { Teleflex } \\
\text { ISIS }\end{array}$ & $\begin{array}{l}7.5 \mathrm{~mm} \text { ETT } \\
\text { High viscosity }\end{array}$ & $\begin{array}{l}\text { Taper- } \\
\text { Guard } \\
\text { EVAC }\end{array}$ & $\begin{array}{l}\text { Portex } \\
\text { SAC- } \\
\text { ETT }\end{array}$ & $\begin{array}{l}\text { Tel- } \\
\text { eflex } \\
\text { ISIS }\end{array}$ \\
\hline $\begin{array}{c}\text { Mean } \pm \text { SD } \\
(\mathrm{ml} / \mathrm{hr})\end{array}$ & $0.00 \pm 0.00$ & $\begin{array}{r}0.24 \\
\pm .77 \\
\end{array}$ & $\begin{array}{r}0.59 \\
\pm 1.28 \\
\end{array}$ & $\begin{array}{c}\text { Mean } \pm \text { SD (ml/ } \\
\mathrm{hr})\end{array}$ & $0.25 \pm .19$ & $1.05 \pm .44$ & $1.17 \pm .52$ & $\begin{array}{c}\text { Mean } \pm \text { SD (ml/ } \\
\mathrm{hr})\end{array}$ & $0.28 \pm .18$ & $\begin{array}{r}0.48 \\
\pm .29 \\
\end{array}$ & $\begin{array}{r}0.49 \\
\pm .39 \\
\end{array}$ \\
\hline $\begin{array}{c}\text { TaperGuard } \\
\text { EVAC }\end{array}$ & & $\mathrm{P}<.27$ & $\mathrm{P}<.08$ & $\begin{array}{c}\text { TaperGuard } \\
\text { EVAC }\end{array}$ & & $\mathrm{P}<.00002$ & $\mathrm{P}<.00004$ & $\begin{array}{c}\text { TaperGuard } \\
\text { EVAC }\end{array}$ & & $\mathrm{P}<.03$ & $\mathrm{P}<.06$ \\
\hline $\begin{array}{l}\text { Portex } \\
\text { SACETT }\end{array}$ & $\mathrm{P}<.27$ & & $\mathrm{P}<.59$ & Portex SACETT & $\mathrm{P}<.00002$ & & $\mathrm{P}<.30$ & Portex SACETT & $\mathrm{P}<.03$ & & $\mathrm{P}<.8$ \\
\hline Teleflex ISIS & $\mathrm{P}<.08$ & $\mathrm{P}<.59$ & & Teleflex ISIS & $\mathrm{P}<.00004$ & $\mathrm{P}<.30$ & & Teleflex ISIS & $\mathrm{P}<.06$ & $\mathrm{P}<.8$ & \\
\hline
\end{tabular}

\begin{tabular}{|c|c|c|c|c|c|c|c|c|c|c|c|}
\hline $\begin{array}{l}9.0 \mathrm{~mm} \text { ETT } \\
\text { Low viscosity }\end{array}$ & \begin{tabular}{|c|} 
TaperGuard \\
EVAC
\end{tabular} & $\begin{array}{c}\text { Portex } \\
\text { SACETT }\end{array}$ & $\begin{array}{l}\text { Teleflex } \\
\text { ISIS }\end{array}$ & $\begin{array}{l}\text { 9.0mm ETT Me- } \\
\text { dium viscosity }\end{array}$ & $\begin{array}{c}\text { TaperGuard } \\
\text { EVAC }\end{array}$ & $\begin{array}{c}\text { Portex } \\
\text { SACETT }\end{array}$ & $\begin{array}{l}\text { Teleflex } \\
\text { ISIS }\end{array}$ & $\begin{array}{c}9.0 \mathrm{~mm} \text { ETT High } \\
\text { viscosity }\end{array}$ & $\begin{array}{c}\text { TaperGuard } \\
\text { EVAC }\end{array}$ & $\begin{array}{c}\text { Portex } \\
\text { SACETT }\end{array}$ & $\begin{array}{c}\text { Teleflex } \\
\text { ISIS }\end{array}$ \\
\hline $\begin{array}{l}\text { Mean } \pm \text { SD } \\
(\mathrm{ml} / \mathrm{hr})\end{array}$ & $0.27 \pm .64$ & $\begin{array}{c}0.95 \\
\pm 1.61\end{array}$ & $\begin{array}{c}1.20 \\
\pm 1.66\end{array}$ & $\begin{array}{c}\text { Mean } \pm \text { SD (ml/ } \\
\mathrm{hr})\end{array}$ & $0.88 \pm .44$ & $1.25 \pm .58$ & $1.63 \pm .85$ & $\begin{array}{c}\text { Mean } \pm \text { SD (ml/ } \\
\text { hr })\end{array}$ & $0.82 \pm .43$ & $1.03 \pm .38$ & $\begin{array}{r}1.41 \\
\pm .88\end{array}$ \\
\hline $\begin{array}{c}\text { TaperGuard } \\
\text { EVAC }\end{array}$ & & $\mathrm{P}<.67$ & $\mathrm{P}<.32$ & $\begin{array}{c}\text { TaperGuard } \\
\text { EVAC }\end{array}$ & & $\mathrm{P}<.04$ & $\mathrm{P}<.002$ & $\begin{array}{c}\text { TaperGuard } \\
\text { EVAC }\end{array}$ & & $\mathrm{P}<.26$ & $\mathrm{P}<.02$ \\
\hline $\begin{array}{c}\text { Portex SAC- } \\
\text { ETT }\end{array}$ & $\mathrm{P}<.67$ & & $\mathrm{P}<.46$ & Portex SACETT & $\mathrm{P}<.04$ & & $\mathrm{P}<.19$ & Portex SACETT & $\mathrm{P}<.26$ & & $\mathrm{P}<.11$ \\
\hline Teleflex ISIS & $\mathrm{P}<.32$ & $\mathrm{P}<.46$ & & Teleflex ISIS & $\mathrm{P}<.002$ & $\mathrm{P}<.19$ & & Teleflex ISIS & $\mathrm{P}<.02$ & $\mathrm{P}<.11$ & \\
\hline
\end{tabular}


Figure 5. Pressure profiles of endotracheal tube cuffs inflated to $25 \mathrm{~cm} \mathrm{H_{2 }} \mathrm{O}$. Left is Hi-Lo and right is TaperGuard. Color scale to the right represents surface pressure in $\mathrm{cm} \mathrm{H}_{2} \mathrm{O}$.
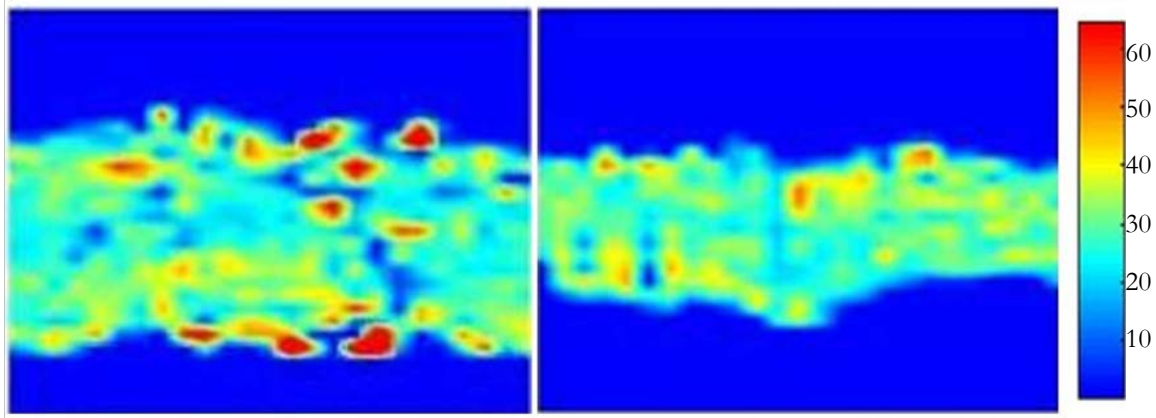

available ETTs with intrinsic subglottic suction capabilities. The silicon base liquids used in our study are standardized solutions with predictable and reproducible viscosities to mimic secretions of different viscosities encountered clinically. The suction protocol times were selected to take into account reported adverse events due to continuous subglottic suction. Lastly, we chose a representative high volume low pressure cuff to measure barrel shaped cuff pressure points in the comparison to the low volume low pressure taper shaped cuff.

In our in vitro model the cuff sealing performance varied considerably (Table 2). This is surprising, since one would assume that tubes of the same size and cuff type would have very similar sealing performance. The taper shaped cuff exhibited the best sealing performance in our model. In terms of subglottic suction efficiency the Teleflex ISIS demonstrated the most efficient suction compared to the other endotracheal tubes in the test. This finding is similar to the results published by Mujica-Lopez et. al. in 2010 [10] although in that publication there was no mention of the viscosity of fluids used. In terms of cuff sealing in the ETTs with intrinsic suction the TaperGuard demonstrated the lowest rate of leak at all mucous viscosities. The most significant finding in this test was that regardless of suction efficiency the endotracheal tube cuffs still allowed fluid to pass at all viscosities. This finding suggests that even with subglottic suction, no tubes prevent microaspiration completely. Although no safe amount of aspiration has been established it is reasonable to assume that the tube resulting in the least amount of aspiration will probably result in less post intubation pulmonary complications [11].

The surface pressure characteristics of the barrel shaped versus the taper shaped cuff were as expected. Although, the barrel shaped had a larger contact area, the surprising finding was that the barrel shaped cuff had areas of pressure that exceeded the cuff inflation pressure as well as areas that were less than the inflation pressure (Figure 5). A possible explanation is that the barrel shaped cuffs have a resting diameter that is larger than the trachea. As a result, folds of cuff material create high pressure and leakage zones within the boundaries of the cuff.

We have reported on the physical findings related to ETT design. The clinical significance of these design differences should be tested in controlled human trials.

\section{Acknowledgement}

We thank Paul Batchelder, BS, LRCP, RRT for technical assistance in performing the study and reviewing the manuscript.

\section{References}

[1]. Leigh JM, Maynard JP (1979) Pressure on the tracheal mucosa from cuffed tubes. BMJ 1(6172): 1173-1174.

[2]. Seegobin RD, Van Hasselt GL (1984) Endotracheal cuff pressure and tracheal mucosal blood flow: Endoscopic study of effects of four large volume cuffs. BMJ 288(6422): 965-968.

[3]. Oikkonen M, Aromaa U (1997) Leakage of fluid around low-pressure tracheal tube cuffs. Anesthesia 52(6): 567-569.

[4]. Rawlinson E, Minchom A (2007) Pulmonary aspiration. Anesthesia and Intensive Care Medicine 8(9): 365-367.

[5]. Macrae W, Wallace P (1981) Aspiration around high-volume, low-pressure endotracheal cuff. Br Med J 283(6301): 1220.

[6]. ISO 5361-1999 (1999) Anesthetic and respiratory equipment -- Tracheal tubes and connectors.

[7]. Inoue H, Ono K, Masuda W, Inagaki T, Yokota M, et al. (2008) Rheological properties of human saliva and salivary mucins. J Oral Biosci 50(2): 134141 .

[8]. Majima Y, Harada T, Shimizu T, Takeuchi K, Sakakura Y, et al. (1999) Effect of biochemical components on rheologic properties of nasal mucus in chronic sinusitis. Am J Respir Crit Care Med 160(2): 421-426.

[9]. Marciani L, Gowland PA, Spiller RC, Manoj P, Moore RJ, et al. (2000) Gastric response to increased meal viscosity assessed by echo-planar magnetic resonance imaging in humans. J Nutr 130(1): 122-127.

[10]. Mujica-Lopez KI, Pearce MA, Narron KA, Perez J, Rubin BK (2010) In vitro evaluation of endotracheal tubes with intrinsic suction. Chest 138(4): 863-869.

[11]. Muscedere J, Rewa O, McKechnie K, Jiang X, Laporta D, et al. (2011) Subglottic secretion drainage for the prevention of ventilator-associated pneumonia: A systematic review and meta-analysis. Crit Care Med 39(8): $1985-1991$ 